\title{
Motivations and Career Decisions in Occupational Therapy Course: A Qualitative Inquiry of Asia-Pacific International Students in Australia
}

\author{
Luis Miguel Dos Santos (D) \\ Endicott College, Woosong University, \\ Daejeon, South Korea
}

\begin{abstract}
Purpose: This study aims to understand the motivations of academic voyage and postgraduation career decisions of occupational therapy international students in Australia. The following two research questions guided this study: why do international students choose to study in Australia instead of ones in their own countries? And why do international students choose to study occupational therapy program(s) in Australia instead of ones in their own countries?
\end{abstract}

Patients and Methods: A qualitative design with phenomenology was employed to recruit 20 participants for the data collection procedures, including interview sessions, focus group activity, and member checking interview. The participants were studying one of the accredited occupational therapy programs in Australia as international students.

Results: Six themes were yielded. All participants expressed that due to the excellent education, reasonable tuition fees and living standard, and the positive career opportunities, almost all expressed their positive experiences of their Australian voyage as international students and tended to stay in Australia after they gained the registration career development. More importantly, the notions of contribution to Australian communities are captured as many considered Australia as an important place in their lives.

Conclusion: University leaders may wish to take action in upgrading their international students' services, particularly career development services. Government agencies may take this study as a blueprint for upgrading the current regulations for international students, particularly in establishing a targeted immigration visa for recent graduates who want to establish their own businesses or invest in Australia.

Keywords: medical education, medical staff shortage, medical student, occupational therapy education, social cognitive career theory, social cognitive career and motivation theory, workforce shortage

\section{Introduction}

\section{Background}

Australia is one of the most popular destinations for international students who want to study abroad away from their home country. ${ }^{1,2}$ According to the Australian Department of Education, Skills and Employment, international student populations in Australia increased rapidly from the early 2000s to late-2020. In 2018, 316,980 international students enrolled in Australian higher education, while 138,178 registered in VET (Vocational Education and Training) centers. ${ }^{3}$ In the less than five years since then, however, international student enrolment has increased to 360,659
Correspondence: Luis Miguel Dos Santos 196-5 Jayang Dong, Daejeon, 345I4, South Korea

Tel +82 I0-3066-78I8

Email luismigueldossantos@yahoo.com 
while enrolment in VET centers has only increased to $190,056 .{ }^{4}$ The rapid expansion of the international student population reflects the confidence of these students and their parents in the educational quality and career opportunities of the Australian education system. Even more importantly, it reflects the faith these parents have in Australian communities as safe places for their children to start a new life chapter in an overseas country. ${ }^{5}$

In the past few years, new technology and distancelearning tools have provided students of diverse backgrounds in remote communities with opportunities to complete a university education online. These changes in capability are reflected in the Australian higher education system. ${ }^{6-8}$ For example, more than half of the universities in Australia offer blended or fully online programs in different majors and subjects. ${ }^{9}$ Particularly in the liberal arts and other theoretical courses that can be conducted with readings, discussions, assignments, and exams from textbooks, students may complete their courses entirely online from any place in the world. ${ }^{9}$ However, for some vocational courses, clinical courses, internships, mentorships, and subjects, hands-on experience is a necessary part of the program.

As in many health and social care professions, the demands placed on occupational therapists are numerous: they are faced with unbalanced workloads, high patient-tocaregiver ratios, low salaries, remote working locations, and highly specialized roles in the health and social care system. ${ }^{10}$ Unlike physicians and nurses working directly with patients in frontline environments, occupational therapists tend to work in rehabilitation facilities and thus are simply considered support staff in the health and social care system. ${ }^{11}$ Further, as the role of occupational therapists is unclear to many patients and members of the general public, secondary school graduates may not select occupational therapy as their top choice of major at university. $^{10,12-14}$

Some studies $^{12,15}$ indicated that Australia has a shortage of health and social care professionals, particularly in regional areas. This is due to the increasing illness rates, a larger patient population, the stress of dealing with difficult patients, and professionals ageing out of the workforce. $^{16-18}$ However, secondary school graduates and professionals choosing a second career continue to follow more popular professional routes such as nursing, physical therapy, and public health. ${ }^{19,20}$ Although members of the general public need additional time to understand each health discipline's background and operation, the Australian government has continued to establish schemes to alleviate the human resources shortages in the health and social care system. ${ }^{21}$ Based on The Bradley Review, Australian government agencies and university leaders both advocated that university departments significantly expand in order to serve the increasing student population 22 better. These students, particularly in the health and social care professions, require expanding the academic programs, courses, lessons, learning outcomes, and majors available to them. Universities followed these recommendations and expanded their academic departments and programs. ${ }^{18}$

The Bradley Review ${ }^{12,22}$ further indicated that overall enrolment at Australian universities would increase significantly due to developments such as improved quality of education and the growing international student population. In the 2020/2021 academic year, according to the Australian Health Practitioner Regulation Agency, 23 universities with more than 60 academic programs in most Australian states (except for Tasmania and the Northern Territory) offered degree programs for bachelor's, master's, and master's (graduate entry) degrees. A recent study $^{12}$ indicated that the in 2014/2015 academic year, 7,952 students enrolled in occupational therapy programs. However, student enrolment dropped to 7,921 for the 2015/2016 academic year. Although enrolment has maintained the same level for the past few years, the patient-totherapist ratio is still unbalanced, particularly in rural areas. According to recommendations from federal government agencies and recent policies for immigration, ${ }^{23}$ the Australian state and federal governments strongly encourage immigrants and skilled professionals to move from urban to rural areas for long-term development. As increasing numbers of people gradually move to rural areas, the demands placed upon health and social care professionals will dramatically increase. ${ }^{18,24-27}$

Different agencies and departments in the Australian government continue to encourage professionals (eg, doctors, nursing professionals, teachers, computer science/ information technology professionals, and blue-collar workers) to move from urban to rural areas. ${ }^{18,24-27}$ For example, as part of their nursing programs, many colleges and TAFE institutions (Technical and Further Education) offer a post-secondary diploma and certificate for secondary school graduates and adults joining the nursing profession. ${ }^{28}$ These academic programs do not require full-time training for four years and therefore allow graduates to join the workforce in a short space of time. ${ }^{29}$ 
However, as occupational therapy is not very widely known to secondary school graduates and professionals choosing a second career, the human resources shortage in this area cannot be filled immediately. ${ }^{30}$

\section{Purpose and Significance of the Study}

Based on the social cognitive career and motivation theory, ${ }^{31}$ this study aims to understand the motivations of the academic voyage and post-graduation career decisions of occupational therapy students currently enrolled in accredited academic programs in Australia and focuses particularly on the motivations of study decision-making process of international students. ${ }^{32}$ Currently, many studies $^{16,33,34}$ in this area focus on the career decisions of health and social care professionals such as counsellors and nursing professionals. However, as occupational therapy is not as popular a career choice as nursing, for example, the results of this study will be useful for government agencies and related organizations in their efforts to manage the human resources shortages in this field. The following two research questions guided this study:

1. Why do international students choose to study in Australia instead of ones in their own countries? What motivates their decisions to Australia?

2. Why do international students choose to study occupational therapy program(s) in Australia instead of ones in their own countries? What motivates their decisions to Australia?

\section{Theoretical Framework: Social Cognitive Career and Motivation Theory}

The social cognitive career and motivation theory ${ }^{31}$ guided this study for occupational therapy students' motivations and career decisions in the Australian environment, particularly international students. The social cognitive career and motivation theory was developed based on the social cognitive career theory, ${ }^{35}$ self-efficacy approach ${ }^{36,37}$ and social cognitive theory. ${ }^{38}$ The social cognitive career theory seeks to understand the relationship between internal/ personal factors and social/environmental factors related to the individuals' career developments and decisions. Researchers ${ }^{19,33,35,39}$ have argued that individuals may be influenced by one or more factors in their surrounding environments and people. Through detailed investigations, researchers may understand the social trends and recommend solutions to the appropriate agencies.
Since human communities have changed socially and financially since the social cognitive career theory was first developed, the factors were recently updated. ${ }^{31}$ As a result, the social cognitive career and motivation theory ${ }^{31}$ was employed to reflect the contemporary situation better. Based on the additional enhancements and developments, the social cognitive career and motivation theory has two directions, including 1) the psychological and internal factors with self-efficacy with academic interests, personal considerations, and achievements of education and career goals, and 2) social and external factors with interests in career development, financial considerations, and surrounding environments and individuals. Please refer to Figure 1 for details.

\section{Materials and Methods}

The qualitative design was employed in this study. Phenomenology ${ }^{40}$ with interpretivism ${ }^{41}$ was appropriate to understand this social phenomenon in the Australian community. The phenomenology allowed the researcher to capture the voices and comments of the participants who face similar issues and problems in the community. In other words, the wider picture and population may be included in the phenomenological study. ${ }^{42}$ Based on the rationale of this study (ie the motivations and career decisions of occupational therapy students who are currently enrolled in one of the accredited academic programs in Australia as international students), the wider populations

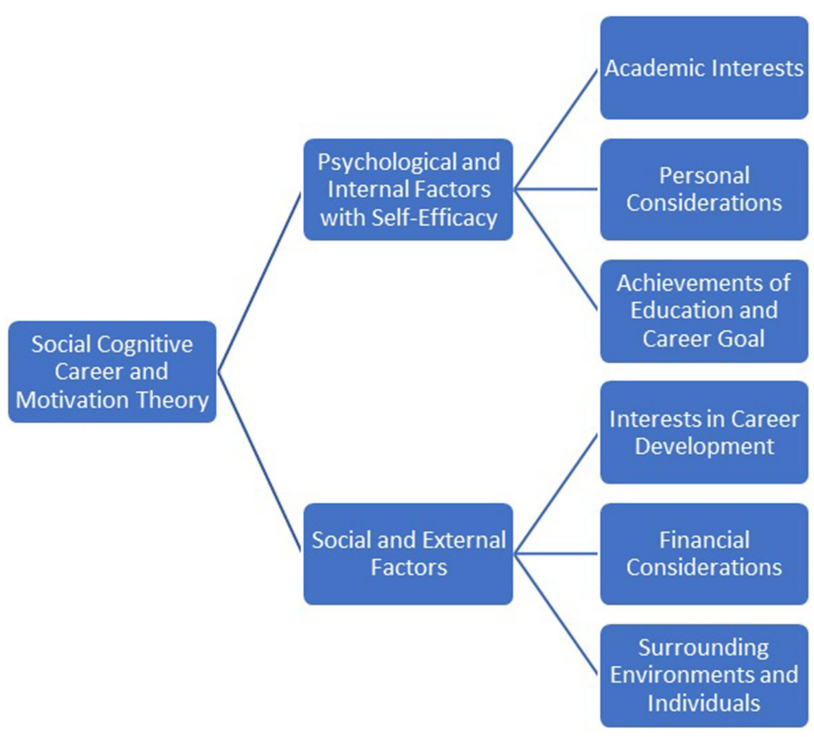

Figure I Social cognitive career and motivation theory.

Note: Adapted from Dos Santos LM. Developing bilingualism in nursing students: learning foreign languages beyond the nursing curriculum. Healthcare. 2021;9 (3):326. doi: $10.3390 /$ healthcare 9030326 . $^{31}$ 
and perspectives from students all across Australia should be captured. Therefore, after careful consideration, phenomenology was employed.

\section{Participants, Recruitments, and Data Collection}

The snowball sampling strategy ${ }^{42,43}$ was employed to recruit students with a similar background. First of all, the researcher contacted three potential participants for the recruitment based on the referral from a school department head. Once the participants agreed with the participation verbally, the researcher sent the invitation letter, interview protocol, rationale of the study, unsigned agreement, and related materials to the potential participant. Once the participants completed the interview session(s), the participant should refer at least one participant who met the criteria of the study. After several rounds of the referral and recommendations, 20 participants were invited. Ten male and ten female participants were invited. Three first-year, four second-year, eight third-year, and five final-year students joined the study. All of them were traditional-age and self-funded international students with some lesser scholarships.

Qualitative researchers ${ }^{44}$ should build up the interpersonal relationship(s) between the researchers and the participants. Therefore, multiple interview sessions should be employed. For this study, in order to establish the relationship, the researcher employed two interview sessions for each participant. For the interview sessions, as the researcher is based in South Korea, the face-to-face interview sessions could not be conducted. Therefore, distancebased, one-on-one, semi-structured, and private interview sessions were conducted. The first interview session focused on the questions about the experiences before their Australian education. The second session focused on the questions about the experiences during the time in Australia. Each interview session lasted from 65 to 108 minutes.

After the participants completed two interview sessions with the researcher, all were invited to the focus group activities (ie focus group discussions) for further sharing. Each focus group activity involved five participants. Therefore, four focus group activities were formed. During the focus group activities, the researcher asked the questions, and the participants discussed and shared their answers in the distance-based focus group activity room via video conference. Each focus group activity lasted from 78 to 113 minutes.

After the researcher grouped the materials (ie summary of the transcripts of the interview sessions and focus group activities) based on each participant, the researcher sent the related materials to each participant appropriately for the member checking confirmation. Then, the researcher invited each member checking interview (ie for the confirmation of their summary). During the member checking interview, the researcher asked the participants to confirm their sharing and stories from the interview sessions and focus group activities. All participants agreed with their summary. The member checking interview session(s) lasted from 18 to 32 minutes. During the data collection procedures, a digital recorder was used to record the voiced messages (ie conversations of the interview sessions, focus group activities, and member checking interview). No visual information could be recorded due to privacy. All participants agreed with this arrangement.

\section{Data Analysis}

First, the researcher transcribed all the voiced messages to written transcripts. Due to the rich and meaningful sharing, more than 800 pages were merged. The researcher re-read the written transcripts multiple times for any potential groups and themes. The researcher employed the opencoding technique based on phenomenology ${ }^{40}$ and grounded theory ${ }^{45}$ for the first-level themes. From this point, the researcher could group 27 themes. However, qualitative researchers ${ }^{42,43,46-48}$ advocated that further developments should be employed. Therefore, the researcher employed the axial-coding technique for the second-level themes. As a result, six were yielded.

\section{Human Subject Protection}

Privacy for all parties is the most important part of this study. All signed written informed consent forms, personal contacts, email addresses, voiced messages, written transcripts, computer, and related materials were locked in a password-protected cabinet. Only the researcher could read the materials. After the researcher completed the study, the related materials were deleted and destroyed for privacy.

The researcher received the support from the appropriate university department and followed the guidelines of the Declaration of Helsinki. All subjects gave their informed agreements and consent form for inclusion before they participated in this study. The study was 
exercised in accordance with the Declaration of Helsinki, and this study was approved by the Woosong University Academic Research Funding 2021 (confirmation: 2020-08/ 2021-05).

\section{Results and Discussion}

After several rounds of interview sessions and focus group activities, the researcher captured six themes, including 1) Personal consideration: The Australian communities, 2) Immigration to Australia: Regional communities as a possible destination, 3) Financial considerations: Balanced, 4) High salary for health and social care professionals, 5) Interest in career development: My own clinics, and 6) Higher social status. Although these participants were studying occupational therapy academic programs in different parts of the country, many of their ideas and comments were similar. Many of them expressed interest in developing their careers in Australia after finishing university.

\section{Personal Considerations: The Australian Communities}

Personal considerations are one of the key factors in the social cognitive career and motivation theory. ${ }^{31}$ Based on the qualitative data, all 20 participants expressed interest in Australian communities before they came for university education. Over half of the participants (11) made a short visit to Australia as teenagers. Many participants also liked the Australian lifestyle and, based on their positive experiences there, decided to come to Australia for an occupational therapy program. A participant said,

... I want to study in Australia because the country is beautiful and nice ... I want to spend my university duration ... in this country and this university ... I came to Australia when I was a middle school student ... after that time, I am sure Australia is a place for me to study and spend my further ... job and future ... (Participant \#8, Korea, Focus Group)

Many participants believed that their previous experiences of Australia had influenced their intention to study abroad or pursue further university education in Australia. The researcher asked them about the differences between domestic and Australian university programs. All stated that they are impressed with the quality of education in Australia. Two participants commented,

... I was accepted in a top-tier university in Australia ... first, I love the weather and the living environment ...
I also love the university ... and the excellent occupational therapy program ... when I received my offer letter, I know ... I will spend my time in Australia ... (Participant \#11, China, Interview)

... I received three offers from the Group of Eight universities ... I believe Australia is welcoming me for the education ... also, the quality of the courses and universities are much better ... in Australia than my country ... so I want to study abroad and learn the good practices from my teachers in Australia ... (Participant \#13, Japan, Focus Group Activity)

Besides the high quality of education (ie reputation of the academic programs and universities), participants also mentioned the influence of relatives and friends, especially of cousins and classmates studying in Australia. One participant commented,

... my cousin is studying physical therapy ... at the same university ... we are in the same faculty ... I was encouraged by my cousin ... because my cousin told me that ... Australia is a good place ... good academic programs ... and good future after university ... (Participant \#16, Hong Kong, Interview)

In short, based on the social cognitive career and motivation theory ${ }^{31}$ factors in the external environment (eg, pleasant weather, the high reputation of the academic programs and universities, and word of mouth from relatives and friends) are important motivators in these students' academic and career decisions. Previous studies ${ }^{49-52}$ indicated that many international students decide to study abroad based on word of mouth and the university's reputation. The findings given here may confirm this trend.

\section{Immigration to Australia: Regional Communities as a Possible Destination}

Australia is a welcoming destination for skilled immigrants and professionals from foreign countries; professionals who met certain criteria may apply for residency via a skilled immigration program. ${ }^{53}$ All 20 participants expressed interest in an immigration program and their desire to develop their careers in Australia after graduation. One participant said,

... I will live in Australia ... because Australia gives me a lot ... I learned the practices ... I will gain the registration ... I spend many years here ... I think I belong to Australia ... I will give up my citizenship if the Australian 
government grants me the citizenship ... (Participant \#7, Korea, Interview)

Besides the external consideration of residency, some participants shared more specifically where they hoped to live in the future. More than three-quarters of the participants indicated that they intend to work in rural communities after university. Two said,

... the vacancies and employments in the metropolitans are filled ... I want to go to the regional areas ... as the employers may sponsor my visa in the future ... also, I can see the job opportunities in the regional areas ... (Participant \#17, Macau, Focus Group Activity)

... the regional areas have a lot of vacancies ... I don't want to live in the regional ... but I think the vacancies are very attractive in these small towns ... I believe all international students should keep it a try ... (Participant \#18, Singapore, Focus Group Activity)

In conclusion, based on social cognitive career and motivation theory, ${ }^{31}$ external factors such as local weather, reputation, words of mouth, location, and career opportunities after graduation are significant factors in these students' academic and career decisions. Although many of the students who participated in this study may not have gone on to complete their university education in Australia, these external factors impacted their decision to consider Australia as a university destination. Based on some previous studies, ${ }^{54,55}$ external factors take important roles in international students' decisions and experiences. The finding of this study confirmed the direction and trend in this area.

\section{Financial Considerations: Balanced}

Many expressed their positive comments about the financial consideration of the Australian standard of living, tuition fees, and professional salary after university graduation. First of all, all 20 participants received more than three university offers from domestic and international universities before coming to Australia. All of the participants were at the top of their classes in secondary school and received scholarship awards (not full scholarships) from different agencies. However, after considering how to balance university expenses, the participants believed Australian universities offered reasonable tuition fees, good degrees, and favorable career opportunities. ${ }^{55}$ Two commented,
... the living costs and tuition fees in Australia ... are cheaper than some other countries ... the United States and Canada for example ... I can work as a part-time worker ... and the scholarships in Australia for international students $\ldots$ are easier to gain ... the registration is internationally recognized ... the degree is excellent ... (Participant \#20, Malaysia, Interview)

... there are many scholarships for international students ... both undergraduate and postgraduate students ... at least people can try to apply ... but other countries ... they tend to reserve for domestic students ... not all of us ... also, the tuition fees are okay ... I can receive a good degree and recognized license from Australia ... it works in my city ... (Participant \#15, Hong Kong, Focus Group Activity)

According to the social cognitive career and motivation theory, ${ }^{31}$ financial consideration plays a role in individuals' decision-making processes. Most of the participants mentioned the need to balance the factors of tuition fees, living costs, degree outcomes, and registration in their choice to study abroad in Australia. Given the higher fees charged to international students, a foreign degree path is very expensive for many families. With the reflection of some previous studies, ${ }^{19,56,57}$ financial considerations bore an important role in these participants' decision to study abroad.

\section{High Salary for Health and Social Care Professionals}

Post-university career development and career decisions were also important factors. Many previous studies ${ }^{20,58,59}$ indicated that health and social care students expressed interest in joining the field of occupational therapy after university. Particularly in some rural areas, ${ }^{18,60,61}$ the salaries for health and social care professionals are relatively due to a shortage of registered professionals. The researcher captured some interesting comments about the salary of occupational therapists in Australia, including the following,

... the salary is attractive ... better than my country ... also, in some large-size hospital and organizations ... they will sponsor their employees for their master's degree or so ... if I can work in one of those ... I can receive some reimbursement from my employer ... for school in the future ... (Participant \#1, Vietnam, Interview)

Nearly all participants indicated that due to government schemes for rural development, some hospitals and clinics 
in remote areas might provide additional stipends for immigrant professionals:

... some remote hospitals ... received funding from the government ... to increase the salary and bonus for us ... from the urban cities ... it will encourage us to go over there ... I did not think about moving to the regional and remote towns ... but I think the experiences and additional bonuses are great ... I want to make some money ... (Participant \#3, Macau, Focus Group Activity)

In conclusion, with the reflection of some previous studies, ${ }^{19,56,57}$ financial considerations played an important role for all participants, especially given that they were self-funded international students with some lesser scholarships (not full scholarships). However, most believed that the Australian tuition fees and expenses were worth the extra investment, particularly for the internationally recognized degree qualification that they bring. According to the social cognitive career and motivation theory, ${ }^{31}$ this study confirms that financial considerations strongly influence these participants' motivations and career choices.

\section{Interest in Career Development: My Own Clinics}

University education provides preparation for graduates to enter the workforce. ${ }^{29}$ As Australian occupational therapy academic programs are designed to provide pre-service health and social care professionals to gain an internationally recognized professional registration inside and outside of the Australian communities, the graduates of these academic programs are skilled professionals with impressive career opportunities. More than three-quarters of the participants indicated a desire to establish their own clinics after graduation, possibly in Australia. The following participants commented,

... having my own clinics ... will allow ... to have the greatest flexibilities ... I don't want to work for any one or any organizations ... I want to have my business and make my own money ... in Australia ... there is an investment visa for business owner ... I am going to apply it after I finished my degree ... (Participant \#6, Korea, Focus Group Activity)

... I agreed ... I should have my clinics ... if I can gain the registration ... just like many chiropractic professionals ... we can only have our own ... it is hard for us to work in a hospital ... we don't have permanent residency ... but at least we can start a business in Australia ... (Participant \#5, Korea, Interview)

Besides those who wished to start clinics in Australia, more than ten participants hoped to return home and establish their own clinics in their homeland. As two other participants commented,

... no clinics in my homeland for occupational therapy ... so I want to have my own clinics ... there are physical therapy, oriental medicines ... and chiropractic clinics ... but I don't see ... or only a few of occupational therapy ... I think the residents in my homeland need my practice ... I will go back there and have my own clinics ... (Participant \#2, Vietnam, Interview)

... there is a demand for occupational therapists ... who can speak different languages ... there are some local clinics ... but many foreigners cannot enjoy the services ... because many of the therapists cannot communicate with the patients ... so I want to have mine ... at least provide one more option for people ... (Participant \#4, The Philippines, Interview)

Some previous studies ${ }^{19,60-65}$ have noted that health and social care pre-service professionals often work where they interned - they desire to remain in a familiar environment during their first few years of work. In other words, pre-service professionals may work in their interned site after graduation. As many graduates do not have solid experience in management and business operation, data from graduates' entry-level experiences at large organizations may be beneficial in understanding public health management and operation. However, in light of the social cognitive career and motivation theory, ${ }^{31}$ most participants expressed interest in starting their own businesses. This desire to operate a business confirmed another financial consideration for participants: the desire to make profits in the future using their own skills.

\section{Higher Social Status}

More than half of the participants expressed a desire for higher social status as something motivating them to pursue a degree and career in occupational therapy. The researcher asked them why they would select occupational therapy as their university major. Many said that they have interests in public health, health, and social care professions. However, none of them wanted to pursue a nursing career, as they perceived nursing professionals as assistants or second-tier professionals. Although the 
professional reputation of an occupational therapist not as high as that of a doctor, for example, occupational therapists may host their own sessions and prescribe formulas and treatments to patients. On the other hand, nursing professionals do not host their own sessions in clinical environments unless this takes place in nursing clinics. ${ }^{20}$ Two participants commented,

... I enjoy my own work ... I don't want to help people ... I want to help my patients ... but I don't want to help doctors for some minor works in the operation rooms ... I want to have the control and my own control in the clinics ... therapists can do that in their own room ... the role is higher than the nurses ... (Participant \#9, Brunei, Focus Group Activity)

... besides doctors and nurses ... there are much medical staff in the hospital ... but I think therapists have a good view and good status ... at least we can provide treatment to our patients ... nurses are the assistants of us ... we are working in the same places ... but there are differences ... (Participant \#10, China, Interview)

In conclusion, given participants' comments, career development is a third factor in the social cognitive career and motivation theory ${ }^{31}$ that influences these students' decisions. Many have a clear desire to operate their own businesses in Australia or their homelands after graduation. However, the findings of this study differ from several other studies. Many previous studies ${ }^{19,60-65}$ indicated that recent health graduates want to work where they interned. However, it is significant that most of the participants interviewed here wanted to start their own clinics after graduation. Further, many participants opined that their social status would be increased by working in occupational therapy rather than as nursing professionals. This confirms that the participants understand the professional position and possible career developments of their chosen occupation. ${ }^{19,33,35,66}$

\section{Limitations and Future Research Directions}

First, the only students interviewed were in occupational therapy programs. It is worth noting that other health and social care fields (such as nursing, physical therapy, etc.) face the same human resources shortages. Therefore, future research should collect data from other students in other healthcare professions.

Second, based on the snowball sampling strategy, the researcher could only recruit and invite students from the Asia-Pacific regions such as South Korea and Japan: participants from other international regions could not be invited due to limitations on the researcher's network, the referral(s) from other participants, and contact groups. Therefore, future researchers may wish to recruit data from international students from the Western hemisphere.

\section{Contributions and Conclusion}

First, university leaders may wish to take action in upgrading their international students' services and centers, particularly career development and investment services. As more international students come to Australia for university, demands for services and assistance will rapidly increase. Without student services and other help of this kind, international students may be disoriented by the unfamiliar environment and perhaps less likely to remain in their programs abroad. Moreover, the career development service may provide workshops as many international students in non-business programs may want to invest in their companies after university graduation. Based on the sharing from the participants, this service may be needed.

Second, government agencies and policymakers may take this study as a blueprint for upgrading the current regulations for international students, particularly in establishing a targeted immigration visa for recent graduates who want to establish their own businesses or invest in Australian communities. As investment is one of the most important factors in general Australian economic development, appropriate help and policy assistance in this area would be extremely impactful and beneficial.

Last but not least, regardless of their academic background or professional field, many international students desire to stay in Australia for career development after graduation. As Australian communities actively develop rural areas, these graduates will become a workforce for the human resources gaps created. Both local and state government agencies should co-establish schemes to retain these skilled professionals, particularly by improving local experiences and registration.

\section{Acknowledgments}

This study was supported by Woosong University Academic Research Funding 2021.

\section{Disclosure}

The author reports no conflicts of interest in this work.

\section{References}

1. Ling C, Tran L. Chinese international students in Australia: an insight into their help and information seeking manners. Int Educ J Comp Perspect. 2015;14(1):42-56. 
2. Gribble C, Rahimi M, Blackmore J. International students and poststudy employment: the impact of university and host community engagement on the employment outcomes of international students in Australia. In: Tran L, Gomes C editors. International Students Connectedness and Identity. Springer; 2017:15-39. doi:10.1007/ 978-981-10-2601-0_2.

3. International Student in Australia Statistics. Study in Australia; 2021. Available from: https://www.studying-in-australia.org/internationalstudent-in-australia-statistics/. Accessed April 11, 2021.

4. Australian trade and investment commission. Education data. Australian Trade and Investment Commission; 2021. Available from: https://www.austrade.gov.au/australian/education/educationdata/current-data/summaries-and-news. Accessed July 21, 2021.

5. Clifford KM, Brander RW, Trimble S, Houser C. Beach safety knowledge of visiting international study abroad students to Australia. Tour Manag. 2018;69:487-497. doi:10.1016/j. tourman.2018.06.032

6. Safford K, Stinton J. Barriers to blended digital distance vocational learning for non-traditional students. Br J Educ Technol. 2016;47 (1):135-150. doi:10.1111/bjet. 12222

7. Simpson O. Supporting Students in Online, Open and Distance Learning. Routledge; 2018. doi:10.4324/9780203417003

8. Simonson M, Smaldino S, Albright M, Zvacek S. Teaching and Learning at a Distance: Foundations of Distance Education. 4th ed. Pearson; 2008.

9. Reiach S, Averbeck C, Cassidy V. The evolution of distance education in Australia: past, present, future. Q Rev Distance Educ. 2012;13 (4):247-252.

10. Seruya FM, Garfinkel M. Caseload and workload: current trends in school-based practice across the United States. Am J Occup Ther. 2020;74(5):7405205090p1. doi:10.5014/ajot.2020.039818

11. Dwinijanti L, Adhikara MFA, Kusumapradja R. Job satisfaction and turnover intention among public sector nurses: is workload and burnout the issue? JEMA J Ilm Bid Akunt Dan Manaj. 2020;17 (1):67-77. doi:10.31106/jema.v17i1.4951

12. Fay P, Adamson L. Is there an occupational therapy employment crisis within Australia? An investigation into two consecutive cohorts of occupational therapy graduates from a single Victorian University identifying trends in employment. Aust Occup Ther J. 2017;64 (6):466-476. doi:10.1111/1440-1630.12432

13. Eismann MM, Weisshaar R, Capretta C, Cleary DS, Kirby AV, Persch AC. Characteristics of students receiving occupational therapy services in transition and factors related to post-secondary success. Am J Occup Ther. 2017;71(3):7103100010p1. doi:10.5014/ ajot.2017.024927

14. VanPuymbrouck L, Friedman C. Relationships between occupational therapy students' understandings of disability and disability attitudes. Scand J Occup Ther. 2020;27(2):122-132. doi:10.1080/ 11038128.2019.1596310

15. Jacob ER, McKenna L, D'Amore A. Educators' expectations of roles, employability and career pathways of registered and enrolled nurses in Australia. Nurse Educ Pract. 2016;16(1):170-175. doi:10.1016/j.nepr.2015.05.011

16. Russell DJ, Zhao Y, Guthridge S, et al. Patterns of resident health workforce turnover and retention in remote communities of the Northern Territory of Australia, 2013-2015. Hum Resour Health. 2017;15(1):52. doi:10.1186/s12960-017-0229-9

17. Hay M, Mercer AM, Lichtwark I, et al. Selecting for a sustainable workforce to meet the future healthcare needs of rural communities in Australia. Adv Health Sci Educ. 2017;22(2):533-551. doi:10.1007/ s10459-016-9727-0

18. McManamny T, Jennings PA, Boyd L, Sheen J, Lowthian JA. Paramedic involvement in health education within metropolitan, rural and remote Australia: a narrative review of the literature. Aust Health Rev. 2020;44(1):114. doi:10.1071/AH17228
19. Dos Santos LM. I want to become a registered nurse as a non-traditional, returning, evening, and adult student in a community college: a study of career-changing nursing students. Int J Environ Res Public Health. 2020;17(16):5652. doi:10.3390/ ijerph17165652

20. Dos Santos LM. I am a nursing student but hate nursing: the East Asian perspectives between social expectation and social context. Int J Environ Res Public Health. 2020;17(7):2608. doi:10.3390/ ijerph17072608

21. Looi JC, Maguire P. Surviving the heart of darkness: reflections on the experience of psychiatrists working in public mental health services in Australia. Australas Psychiatry. 2019;27(6):634-636. doi:10.1177/1039856219866365

22. Birrell B, Edwards D. The Bradley Review and access to higher education in Australia. Aust Univ Rev. 2009;51(1):4-13.

23. Regional migration: designated regional areas; 2021. Available from: https://immi.homeaffairs.gov.au/visas/working-in-australia/regionalmigration/eligible-regional-areas. Accessed April 12, 2021.

24. Somerville M, Plunkett M, Dyson M. New teachers learning in rural and regional Australia. Asia-Pacific J Teach Educ. 2010;38(1):39-55. doi:10.1080/13598660903474130

25. Krivokapic-Skoko B, Reid C, Collins J. Rural cosmopolitism in Australia. J Rural Stud. 2018;64:153-163. doi:10.1016/j. jrurstud.2018.01.014

26. Halsey J, Drummond A. Reasons and motivations of school leaders who apply for rural, regional and remote locations in Australia. Aust Int J Rural Educ. 2014;24(1):69-77.

27. White S, Lock G, Hastings W, Cooper M, Reid JA, Green W. Investing in sustainable and resilient rural social space: lessons for teacher education. Educ Rural Aust. 2011;21(1):67-78.

28. Currie J, Kourouche S, Gordon C, Jorm C, West S. Mass casualty education for undergraduate nursing students in Australia. Nurse Educ Pract. 2018;28:156-162. doi:10.1016/j.nepr.2017.10.006

29. Ryan M, Gwinner K, Mallan K, Livock C. Preparing work-ready nurses: reflexive learning for diverse students in the Australian vocational education and training sector. Stud Contin Educ. 2017;39 (3):268-285. doi:10.1080/0158037X.2017.1279136

30. Faithfull-Byrne A, Thompson L, Welch T, Williamson M, Schafer K, Hallinan C. Back to the future: a practice led transition program from assistant in nursing to enrolled nurse. Nurse Educ Pract. 2017;22:83-88. doi:10.1016/j.nepr.2016.11.005

31. Dos Santos LM. Developing bilingualism in nursing students: learning foreign languages beyond the nursing curriculum. Healthcare. 2021;9(3):326. doi:10.3390/healthcare9030326

32. Dos Santos LM. Career decision of recent first-generation post-secondary graduates at a metropolitan region in Canada: a social cognitive career theory approach. Alberta J Educ Res. 2018;64(2):141-152.

33. Dos Santos LM. How does COVID-19 pandemic influence the sense of belonging and decision-making process of nursing students: the study of nursing students' experiences. Int $J$ Environ Res Public Health. 2020;17(15):5603. doi:10.3390/ ijerph17155603

34. Gupta N, Diallo K, Zurn P, Dal Poz MR. Assessing human resources for health: what can be learned from labour force surveys? Hum Resour Health. 2003;1(1):5. doi:10.1186/1478-4491-1-5

35. Lent RW, Brown SD, Hackett G. Toward a unifying social cognitive theory of career and academic interest, choice, and performance. J Vocat Behav. 1994;45(1):79-122. doi:10.1006/jvbe.1994.1027

36. Bandura A. Self-Efficacy in Changing Societies. Cambridge University Press; 1995.

37. Bandura A. Self-efficacy mechanism in human agency. Am Psychol. 1982;37(2):122-147. doi:10.1037/0003-066X.37.2.122

38. Bandura A. Human agency in social cognitive theory. Am Psychol. 1989;44:1175-1184. doi:10.1037/0003-066X.44.9.1175 
39. Lent RW, Brown SD. Social cognitive approach to career development: an overview. Career Dev Q. 1996;44(4):310-321. doi:10.1002/ j.2161-0045.1996.tb00448.x

40. Giorgi A. Phenomenology and Psychological Research. Duquesne University Press; 1985.

41. Burrell G, Morgan G. Sociological Paradigms and Organisational Analysis: Elements of the Sociology of Corporate Life. Heinemann; 1979.

42. Merriam SB. Qualitative Research: A Guide to Design and Implementation. Jossey Bass; 2009.

43. Creswell J. Qualitative Inquiry and Research Design: Choosing Among Five Approaches. Sage; 2012.

44. Seidman I. Interviewing as Qualitative Research: A Guide for Researchers in Education and the Social Sciences. 4th ed. Teachers College Press; 2013.

45. Strauss A, Corbin JM. Basics of Qualitative Research: Grounded Theory Procedures and Techniques. Sage; 1990.

46. Tang KH, Dos Santos LM. A brief discussion and application of interpretative phenomenological analysis in the field of health science and public health. Int J Learn Dev. 2017;7(3):123-132. doi:10.5296/ ijld.v7i3.11494

47. Dos Santos LM. Stress, burnout, and low self-efficacy of nursing professionals: a qualitative inquiry. Healthcare. 2020;8(4):424. doi: $10.3390 /$ healthcare 8040424

48. Dos Santos LM. Recruitment and retention of international school teachers in remote archipelagic countries: the Fiji experience. Educ Sci. 2019;9(2):132. doi:10.3390/educsci9020132

49. Yang M, Webster B, Prosser M. Travelling a thousand miles: hong Kong Chinese students' study abroad experience. Int J Intercult Relations. 2011;35(1):69-78. doi:10.1016/j.ijintrel.2010.09.010

50. Merchant A, Rose GM, Moody G, Mathews L. Effect of university heritage and reputation on attitudes of prospective students. Int J Nonprofit Volunt Sect Mark. 2015;20(1):25-37. doi:10.1002/ nvsm. 1515

51. Leong P. Coming to America: assessing the patterns of acculturation, friendship formation, and the academic experiences of international students at a U.S. college. J Int Stud. 2015;5(4):459-474. doi:10.32674/jis.v5i4.408

52. Dos Santos L, Lo HF. The development of doctoral degree curriculum in England: perspectives from professional doctoral degree graduates. Int $J$ Educ Policy Leadersh. 2018;13(6):n6. doi:10.22230/ijepl.2018v13n6a781

53. Robertson S. Student switchers and the ergulation of residency: the interface of the individual and Australia's immigration regime. Popul Space Place. 2011;17(1):103-115. doi:10.1002/psp.598
54. Choudaha R. Campus readiness for supporting international student success. J Int Stud. 2016;6(4):I-V. doi:10.32674/jis.v6i4.318

55. Edgeworth K, Eiseman J. Going bush: international student perspectives on living and studying at an Australian rural university campus. J Res Rural Educ. 2007;22(9):1-13.

56. Thatcher A, Zhang M, Todoroski H, Chau A, Wang J, Liang G. Predicting the impact of COVID-19 on Australian universities. J Risk Financ Manag. 2020;13(9):188. doi:10.3390/jrfm13090188

57. Sanchez-Serra D, Marconi G. Increasing international students' tuition fees: the two sides of the coin. Int High Educ. 2018;(92):13-14. doi:10.6017/ihe.2018.92.10278

58. Ten Hoeve Y, Castelein S, Jansen G, Roodbol P. Dreams and disappointments regarding nursing: student nurses' reasons for attrition and retention. A qualitative study design. Nurse Educ Today. 2017;54:28-36. doi:10.1016/j.nedt.2017.04.013

59. Lin C, Huang C, Kao C, Lu M. The nusring shortage and nursing retention strategies in Taiwan. J Nurs. 2013;60(3):88-93.

60. Kozhimannil KB, Casey MM, Hung P, Han X, Prasad S, Moscovice IS. The rural obstetric workforce in US hospitals: challenges and opportunities. J Rural Health. 2015;31(4):365-372. doi:10.1111/jrh.12112

61. Dos Santos LM. Rural public health workforce training and development: the performance of an undergraduate internship programme in a rural hospital and healthcare centre. Int J Environ Res Public Health. 2019;16(7):1259. doi:10.3390/ijerph16071259

62. Reyes H, Hartin V, Loftin C, Davenport D, Carter V. The impact of employment on nursing students' academic performance. Nurse Educ. 2012;37(5):218-221. doi:10.1097/NNE.0b013e318262abc9

63. Kenny A, Dickson-Swift V, DeVecchi N, Phillips C, Hodge B, Masood Y. Evaluation of a rural undergraduate nursing student employment model. Collegian. 2021;28(2):197-205. doi:10.1016/j. colegn.2020.07.003

64. Curran VR, Fleet L, Kirby F. Factors influencing rural health care professionals' access to continuing professional education. Aust $J \quad$ Rural Health. 2006;14(2):51-55. doi:10.1111/j.14401584.2006.00763.x

65. Ricketts TC. The changing nature of rural health care. Annu Rev Public Health. 2000;21(1):639-657. doi:10.1146/annurev. publhealth.21.1.639

66. Zhang M, Yu Y. Nurse Workforce and Nurse Practitioner System: Vision and Challenges. National Health Research Institutes; 2010.
Advances in Medical Education and Practice

\section{Publish your work in this journal}

Advances in Medical Education and Practice is an international, peerreviewed, open access journal that aims to present and publish research on Medical Education covering medical, dental, nursing and allied health care professional education. The journal covers undergraduate education, postgraduate training and continuing medical education including emerging trends and innovative models linking education, research, and health care services. The manuscript management system is completely online and includes a very quick and fair peer-review system. Visit http://www.dovepress.com/testimonials.php to read real quotes from published authors. 